\title{
Tectonic reconstruction of Uda-Murgal arc and the Late Jurassic and Early Cretaceous convergent margin of Northeast Asia-Northwest Pacific
}

\author{
S. D. Sokolov ${ }^{1}$, G. Ye. Bondarenko ${ }^{2}$, A. K. Khudoley ${ }^{3}$, O. L. Morozov ${ }^{1}$, M. V. Luchitskaya ${ }^{1}$, M. I. Tuchkova ${ }^{1}$, and \\ P. W. Layer ${ }^{4}$ \\ ${ }^{1}$ Geological Institute of the Russian Academy of Sciences (GIN RAN), Pyzhevsky Pereulok 7, Moscow, 109017, Russia \\ ${ }^{2}$ Rusneftegaz Co., Altufiev street 2a, Moscow, 127273, Russia \\ ${ }^{3}$ St. Petersburg State University, Geological Department, Universitetskaya nab. 7/9, St. Petersburg, 199034, Russia \\ ${ }^{4}$ Geophysical Institute, University of Alaska Fairbanks, Fairbanks, USA
}

\begin{abstract}
A long tectonic zone composed of Upper Jurassic to Lower Cretaceous volcanic and sedimentary rocks is recognized along the Asian continent margin from the MongolOkhotsk fold and thrust belt on the south to the Chukotka Peninsula on the north. This belt represents the Uda-Murgal arc, which was developed along the convergent margin between Northeast Asia and Northwest Meso-Pacific. Several segments are identified in this arc based upon the volcanic and sedimentary rock assemblages, their respective compositions and basement structures. The southern and central parts of the Uda-Murgal arc were a continental margin belt with heterogeneous basement represented by metamorphic rocks of the Siberian craton, the Verkhoyansk terrigenous complex of Siberian passive margin and the Koni-Taigonos Late Paleozoic to Early Mesozoic island arc with accreted oceanic terranes. At the present day latitude of the Pekulney and Chukotka segments there was an ensimatic island arc with relicts of the South Anyui oceanic basin in a backarc basin. Accretionary prisms of the Uda-Murgal arc and accreted terranes contain fragments of Permian, Triassic to Jurassic and Jurassic to Cretaceous (Tithonian-Valanginian) oceanic crust and Jurassic ensimatic island arcs. Paleomagnetic and faunal data show significant displacement of these oceanic complexes and the terranes of the Taigonos Peninsula were originally parts of the Izanagi oceanic plate.
\end{abstract}

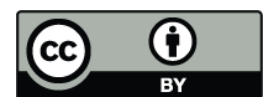

Correspondence to: S. D. Sokolov (sdsokolov@ tochka.ru)

\section{Introduction}

The eastern margin of Northeastern Eurasia records a long history of subduction and terrane accretion through preservation of volcanic arc assemblages, exotic terranes and fold belts reflecting collision. Prominent volcanic arcs are the present activity in Kamchatka and the Late Albian to late Cretaceous Okhotsk-Chukotka volcanic belt (OCVB); however these more recent features obscure the earlier history.

A zone of Upper Jurassic to Lower Cretaceous volcanic and sedimentary rocks is recognized along a $3500 \mathrm{~km}$ long belt along the Asian continent margin from the MongolOkhotsk fold and thrust belt in the south, along the Sea of Okhotsk coastline and via the Pekulney Range to the Chukotka Peninsula in the north (Fig. 1). Sokolov (1992) proposed that these units form the Late Jurassic-Early Cretaceous Uda-Murgal volcanic arc, however each of these units has been studied by different research groups and by different methods, and so their relationship with one another has not been recognized.

The least studied area of this arc is found in the Western Koryak fold and thrust belt, where it contains the Uda-Piyagin, Taigonos, Penzhina-Anadyr, Pekulney and Chukotka segments (Fig. 1). These units form a key area for understanding of many important problems of Northeast Asia tectonics. These problems are: the nature of the Asian and Pacific plates interaction; why the trend of the KoryakKamchatka accretionary structures is nearly normal to the trend of the Verkhoyansk-Chukotka structure which is atypical for the Circum-Pacific belt as a whole; the tectonic setting of tectonostratigraphic units composing the VerkhoyanskChukotka belt, specifically whether they were a part of Panthalassa (Zonenshain et al., 1987; Golonka et al., 1994),

Published by Copernicus Publications on behalf of the European Geosciences Union. 

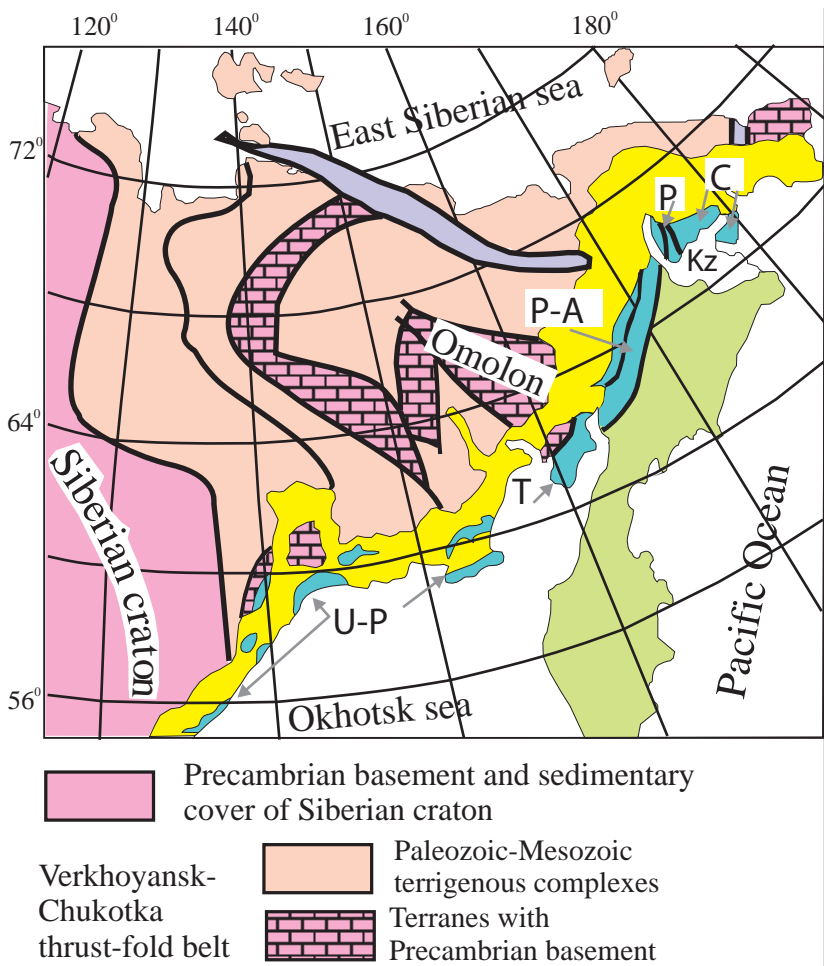

$\square$ Okhotsk-Chukotka volcanic belt
$\begin{aligned} & \square \\ & \square\end{aligned}$ Soryak-Kamchatka thrust-fold belt
$\square$ West-Koryak thrust-fold belt $\quad \mathrm{Kz}$ - Tertiary basin

Segments: U-P - Uda-Piyagin, T - Taigonos, P-A - Penzhina-Anadyr, P - Pekulney, C - Chukotka

Fig. 1. Simplified tectonic map of Northeast Asia (after Silantyev et al., 2001, modified). Segments of the Uda-Murgal arc: U-P - UdaPiyagin segment, T - Taigonos segment, P-A - Penzhina-Anadyr segment, $\mathrm{P}$ - Pekulney segment, $\mathrm{C}$ - Chukotka segment (composed of the Kanchalan, Ushkanegorsk, and Zolotogorsk terranes; Morozov, 2001). Kz - Cenozoic Anadyrskiy sedimentary basin.

or formed as part of unique microplate(s) separated from the Pacific plate by a convergent margin (Sokolov et al., 1997).

In this paper we summarize structural and geochemical data obtained mainly by the authors during their research of the Taigonos Peninsula, and Pekulney Range and Penzhina regions of the Western Koryak fold and thrust belt (Fig. 1). The main purpose of this research is the reconstruction of the convergent boundary, related structures and rock associations formed in the transitional continent-ocean zone in the Late Jurassic and the Early Cretaceous that are referred to here as the Uda-Murgal arc.

\section{Geological background}

In Northeast Russia (Fig. 1) the Verkhoyansk-Chukotka and Koryak-Kamchatka fold and thrust belts are traditionally recognized as important tectonic features in the evolution of northeast Eurasia (Fujita and Newberry, 1983; Parfenov, 1984; Parfenov et al., 1993; Pushcharovsky et al., 1992; Bogdanov and Tilman, 1992; Sokolov et al., 1997). The Verkhoyansk-Chukotka Mesozoic structures have a regional northwest trend and were formed as a result of collision and terrane accretion. Passive and active continental margin complexes as well as large microcontinents such as Omolon, Chukotka and other massifs are widespread. In contrast, structures of the Koryak-Kamchatka fold and thrust belt are mainly northeast trending and represent a typical accretionary continental margin formed by accretion of terranes from the Pacific Ocean basin to the Eurasian continent. Island arc, ophiolite, marginal sea, turbidite, oceanic crust and accretion prism terranes are recognized in this accretionary region (Pushcharovsky and Tilman, 1982; Sokolov, 1992; Parfenov et al., 1993; Nokleberg et al., 1994; Sokolov and Byalobzheskiy, 1996).

Between the Verkhoyansk-Chukotka and KoryakKamchatka fold and thrust belts there is a structural domain called by Markov (1975) "the Western Koryak fold and thrust belt" that was formed in Late Mesozoic (Fig. 1). He described this belt as a tectonic element of the same importance as the Verkhoyansk-Chukotka and Koryak-Kamchatka fold and thrust belts. The Western Koryak fold and thrust belt is greatly discordant to the structural trend of the Verkhoyansk-Chukotka fold and thrust belt and also exhibits some discordance with structures of the Koryak-Kamchatka belt. It consists mainly of island arc complexes ranging in age from Late Paleozoic to Early Cretaceous and accreted ophiolitic, oceanic and island arc terranes of Paleozoic and Mesozoic age (Parfenov, 1984; Sokolov, 1992; Parfenov et al., 1993; Nokleberg et al., 1994). The Western Koryak fold and thrust belt contains deformed rocks of the UdaMurgal arc as well as some older tectonic units for which a relationship with the Uda-Murgal arc is not well established.

Nekrasov (1976) and Zabrovskaya (1978) identified the Koni-Taigonos island arc as being of Permian to Early Mesozoic age and described the Upper Jurassic to Lower Cretaceous volcanic rocks as the orogenic complex that started the evolution of the marginal Okhotsk-Chukotka volcanic belt. Parfenov (1984) suggested that all Permian to lower Cretaceous rock units were formed in a single Uda-Murgal arc and compared it with the modern Kuril island arc. According to Filatova (1988), formation of the Uda-Murgal intraoceanic island arc occurred only in the Late JurassicNeocomian time. Sokolov (1992) argued for the existence of an ancient Late Paleozoic-Early Mesozoic Koni-Taigonos island arc and Late Jurassic-Early Cretaceous Uda-Murgal arc. On the Circum-North Pacific Tectonostratigraphic terrane map (Nokleberg et al., 1994), the Koni-Murgal island 
arc terrane consists of two sub-terranes, which are the Late Jurassic-Early Cretaceous Murgal sub-terrane and the Permian-Neocomian Taigonos sub-terrane. This diversity in ideas regarding age and tectonic evolution of island arc complexes show the necessity of additional research directed to study the evolution of the Asian continent and Northwest Pacific convergent margin and is thus the focus of this paper.

The Late Albian to Late Cretaceous Okhotsk-Chukotka volcanic belt (OCVB) overlies the Verkhoyansk-Chukotka Mesozoic structures and the Western Koryak fold and thrust belt structures with significant regional angular unconformity (Filatova, 1988; Belyi, 1994). Therefore the OCVB may be considered as a post-accretion formation that join together both the Verkhoyansk-Chukotka and Western Koryak fold and thrust belts (Parfenov et al., 1993; Nokleberg et al., 1994; Sokolov et al., 1997).

\section{Geology, geochemistry and structural geology of the Uda-Murgal arc}

Because of the fragmented nature of the Uda-Murgal arc, there is confusion in the literature regarding what defines the arc. Here we follow the definition proposed by Sokolov (1992). We divide the arc into 5 segments: the Uda-Piyagin, Taigonos, Penzhina-Anadyr, Pekulney and Chukotka segments (Fig. 1). For each of these segments we provide a brief geologic summary based on previous work in the region along with new geochemical and structural data that demonstrates the consistent lithology and chronology of the arc.

Most results of our studies on geology of the Uda-Murgal arc have already been published (Sokolov, 1992; Sokolov and Byalobzheskii, 1996; Sokolov et al., 1996, 1997, 2000; Grigoriev et al., 1995; Khudoley and Sokolov, 1998; Bondarenko et al., 1999, 2000; Tuchkova et al., 1999; Silantiev et al., 2000; Luchitskaya, 2001; Luchitskaya et al., 2003) and here we have summarized them in geologic maps and composite stratigraphic columns with accompanying discussion. Most of geochemical data from the Taigonos, Penzhina-Anadyr segment presented in this paper are new and their results and methods of study are presented in Appendix 1 (see: http://www.stephan-mueller-spec-publ-ser. net/4/273/2009/smsps-4-273-2009-supplement.pdf). Geochemical studies of the Pekulney and Chukotka segments have already been published in Russian papers (Morozov, 2000, 2001).

\subsection{Uda-Piyagin segment}

In the Uda-Piyagin segment, the Late Jurassic-Early Cretaceous (Tithonian to Berriasian) mafic, intermediate and acid volcanics, interbedded with pyroclastic and terrigenous rocks deposited in continental environments (Zaborovskaya, 1978; Gromov et al., 1980; Shchepetov, 1995) unconformably overlie Precambrian rocks of the Siberian craton, the Okhotsk cratonic terrane, and Paleozoic to Mesozoic rocks of the Verkhoyansk terrigenous complex. The proportion of volcanic rocks increases southeastward towards the Sea of Okhotsk shoreline, whereas total thickness and stratigraphic volume increase northeastward (Fig. 2). Differentiated calc-alkaline volcanics are typically assumed to be formed in a suprasubductional setting above a high-angle Benioff zone (Parfenov, 1984; Filatova, 1988). The age and correlation of these volcanic and sedimentary rock units is based on flora and, more rarely, fauna fossils. The succession is cut by numerous granite intrusions of calc-alkaline and potassium-sodium series. The only isotopic ages of associated granite intrusions are whole-rock K-Ar dates grouped at 145-142 Ma and 93-66 Ma (Gromov et al., 1980; Lebedev, 1987).

\subsection{Taigonos segment}

Several tectonostratigraphic units are recognized in the Taigonos segment located on the Taigonos Peninsula (Fig. 3). Of these, the Central Taigonos terrane preserves volcanic rocks of the Uda-Murgal arc, whereas the Beregovoi terrane represents an accretionary prism in front of the Uda-Murgal arc.

The northern boundary of the Central Taigonos terrane is the Pylgin shear zone, interpreted as a collision suture formed in Late Mesozoic during closure of the backarc basin of the Late Paleozoic-Early Mesozoic Koni-Taigonos volcanic arc (Bondarenko et al., 2000). The Pylgin shear zone separates the Central Taigonos terrane from the Avekov terrane (Fig. 3) composed of Precambrian and lower Paleozoic metamorphic rocks that are overlapped by deformed Upper Paleozoic to Mesozoic sedimentary cover (Nekrasov, 1976; Zaborovskaya, 1978; Zhulanova, 1990).

The Central Taigonos terrane is composed of the KoniTaigonos and Uda-Murgal arc complexes (Sokolov, 1992). Tithonian-Early Albian volcanic and sedimentary rocks of Uda-Murgal arc (Fig. 4) were deposited in a shallow-marine to continental environments (Nekrasov, 1976; Zaborovskaya, 1978). Differentiated calc-alkaline composition of volcanics implies their original island arc tectonic setting (Nekrasov, 1976; Zaborovskaya, 1978; Filatova, 1988).

To the south, structures of the Central Taigonos terrane are cut by granitoids of the large multistage East-Taigonos pluton (Fig. 3). These granitoids are metaluminous with ASI (Aluminum saturation index $\left(\mathrm{Al}_{2} \mathrm{O}_{3} /\left(\mathrm{CaO}+\mathrm{Na}_{2} \mathrm{O}+\mathrm{K}_{2} \mathrm{O}\right)\right)<1.1$, that is typical for I-type granites in the Chappell and White (1983) classification (Appendix 1, see: http://www.stephan-mueller-spec-publ-ser. net/4/273/2009/smsps-4-273-2009-supplement.pdf). Within the East-Taigonos pluton granodiorite and tonalite predominate, and plagiogranite, quartz monzonite, quartz diorite, diorite and gabbro-diorite are present only in minor amounts. Such variety of igneous rock types as well as the large volume of granitoid magmatism allows correlation of this unit 


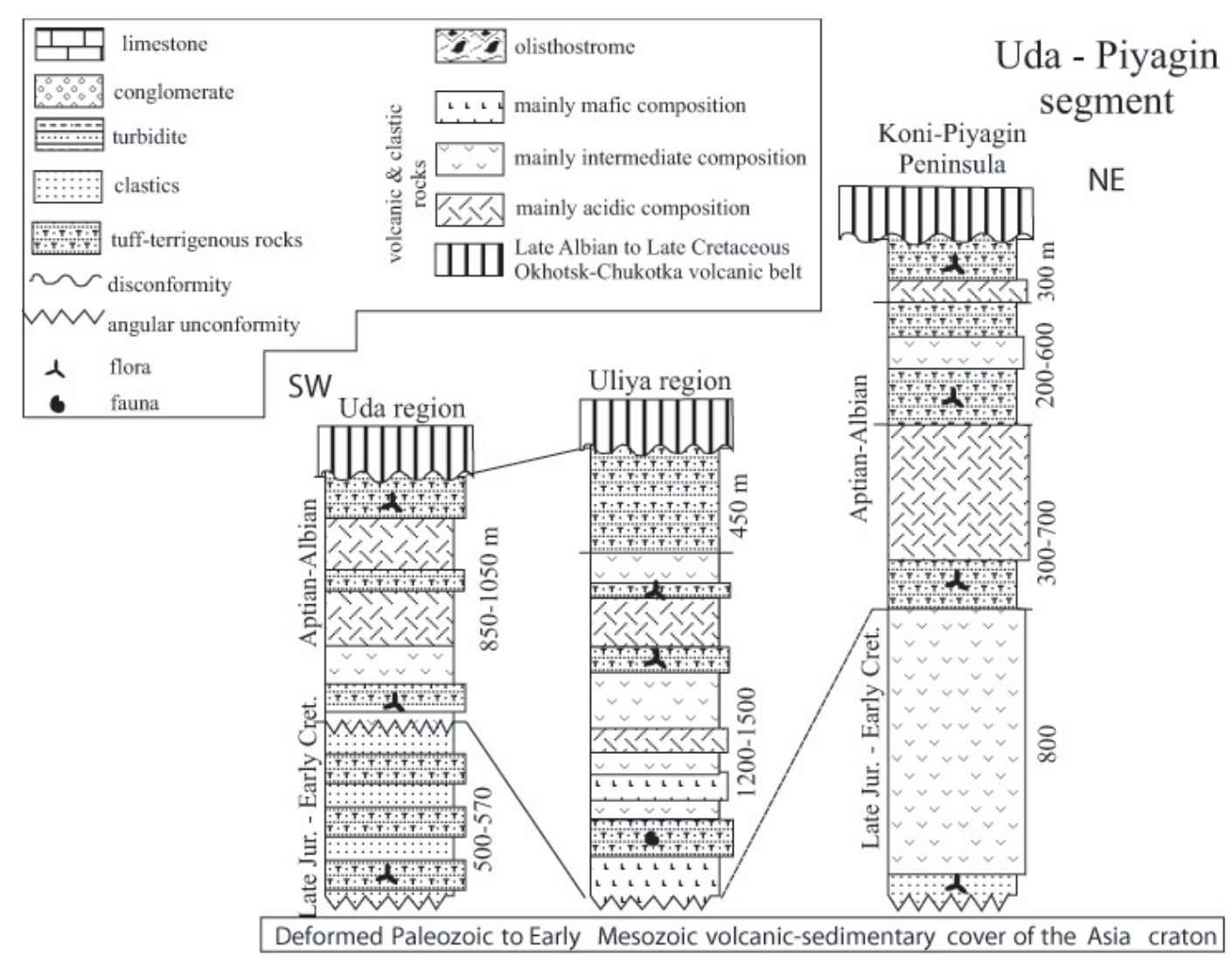

Fig. 2. Stratigraphic sections of the Uda-Piyagin segment. Composite columns are compiled after Migovich (1972), Markov (1975), Gromov et al. (1980), Lebedev (1987), Filatova (1988), and Belyi (1994).

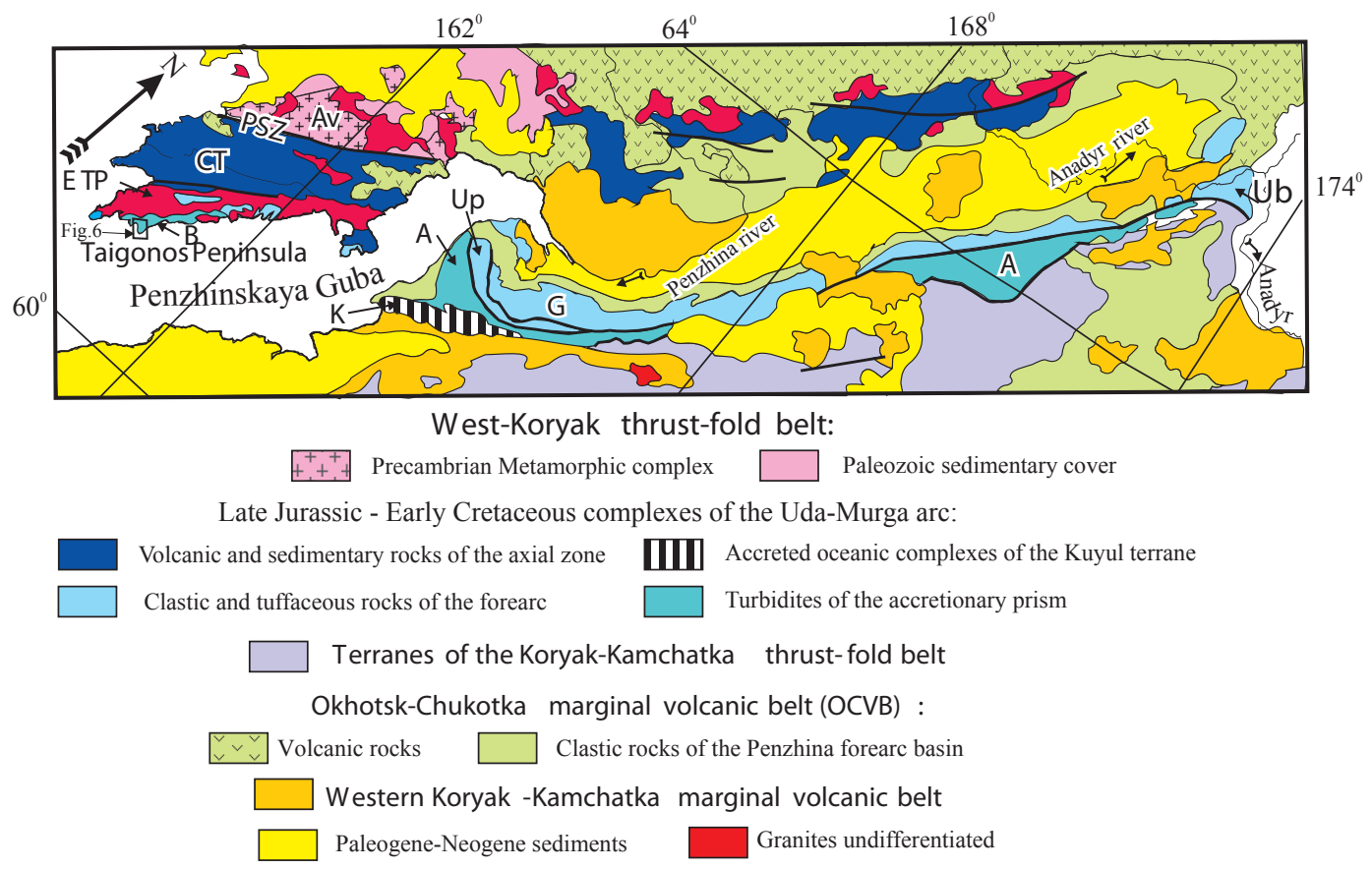

Fig. 3. Tectonic map of the Taigonos and Penzhina - Anadyr segments. Terranes of Taigonos and Penzhina-Anadyr segments: A - Ainyn, Av - Avekov, B - Beregovoi, CT - Central Taigonos, G - Ganychalan, K - Kuyul, Ub - Ust-Belaya, Up - Upukin. Other abbreviations: PSZ - Pylgin shear zone, ETP - East Taigonos pluton. 


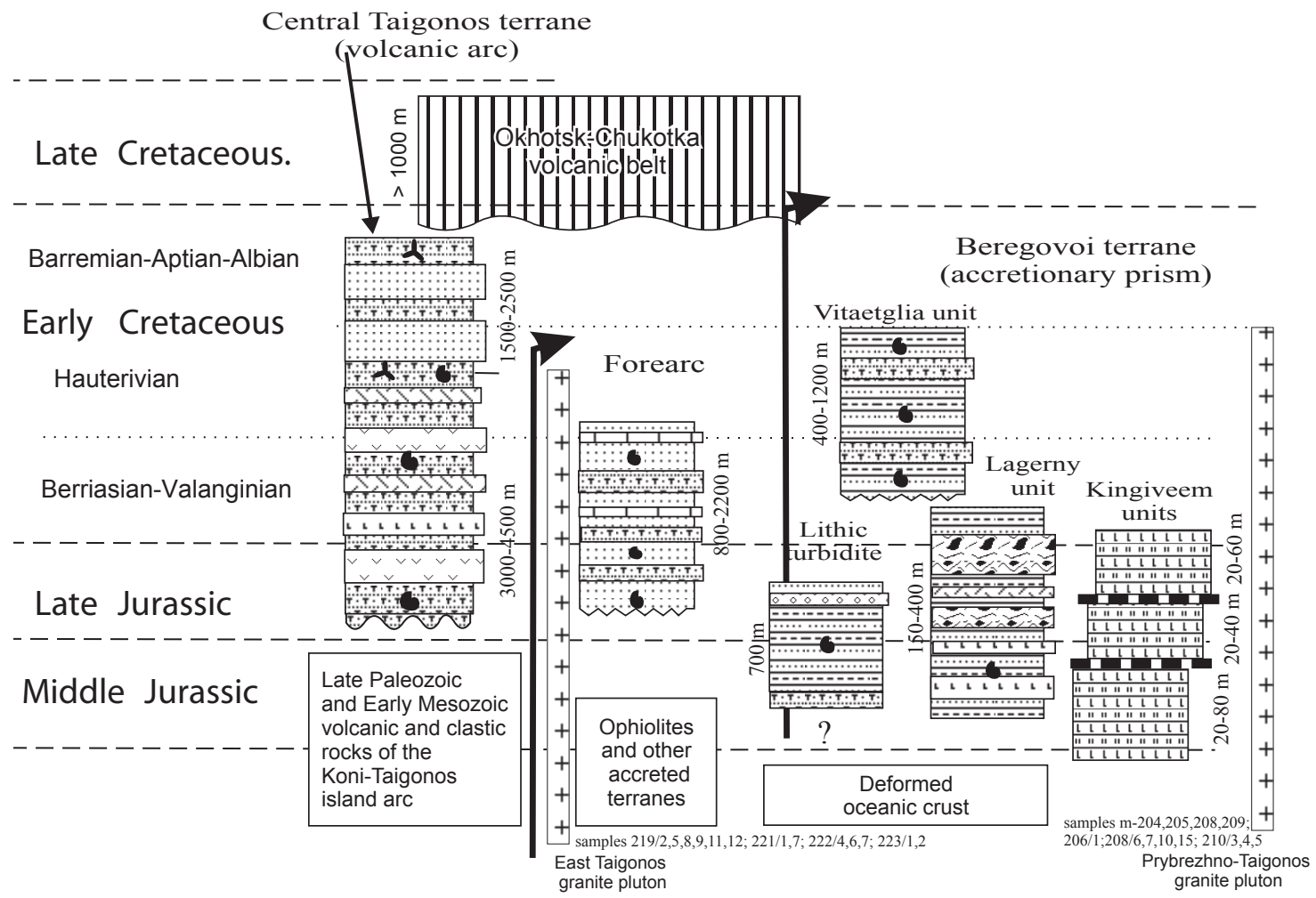

Fig. 4. Tectono-stratigraphic complexes of the Taigonos segment. Compiled by authors with consideration data by Nekrasov (1975) and Zaborovskaya (1976). See Legend in Fig. 2.

to Cordilleran I-type granites of Pitcher (1987, 1993). The observed $\mathrm{Zr}$ versus $(\mathrm{Nb} / \mathrm{Zr})_{n}$ variations in the granitoids suggests formation in a supra-subduction setting (Fig. 5a). On the $\mathrm{Rb}-\mathrm{Y}+\mathrm{Nb}$ diagram granitoids occupy the field of volcanic arc granites (VAG) (Fig. 5b). LILE (large ion lithophile elements) enrichment, HFSE (high field strength elements) depletion, distinct $\mathrm{Ta}$ and $\mathrm{Nb}$ depletion relative to other HFSE shown on diagrams normalized to ocean ridge granite show their affinity with island arc intrusions (Fig. 5c) (Luchitskaya, 2001). Chondrite-normalized patterns of tonalites and granodiorites of the East Taigonos pluton are enriched in LREE (light rare earth elements) and depleted in HREE (heavy rare earth elements). LREE-enriched granites and characterized by a negative Eu-anomaly, whereas diorite from the endocontact zone is slightly enriched in LREE, slightly depleted in HREE, and does not show an Euanomaly (Fig. 5d). ${ }^{40} \mathrm{Ar} /{ }^{39} \mathrm{Ar}$ biotite ages of granodiorite and granite are $103.3 \pm 0.3 \mathrm{Ma}$ and $103.1 \pm 0.5 \mathrm{Ma}$, respectively (Bondarenko et al., 1999). U-Pb SHRIMP (sensitive high resolution ion microprobe) zircon dating shows that zircon crystallization in the granitoids occurred from 97.0 $\pm 1.1 \mathrm{Ma}$ to $104.6 \pm 1.1 \mathrm{Ma}$ (Hourigan, 2003; Luchitskaya et al., 2003), thus providing a lower limit to the age of the Uda-Murgal arc in this region.

Contact between the Central Taigonos terrane and the Beregovoi terrane is represented by a wide shear zone interpreted as a thrust of the East-Taigonos pluton and associ- ated metamorphic rocks onto the Beregovoi terrane, located along the shoreline (Fig. 3). The shear zone contains large blocks in the roof of the granite massif as well as tectonic slices with metamorphosed Paleozoic sedimentary and magmatic rocks in addition to Upper Jurassic-Valanginian tuffs and terrigenous rocks (Nekrasov, 1976; Chekhov and Palandzhyan, 1995). The latter are interpreted as forearc fragments, whereas more ancient rock units are interpreted as forearc basement.

The Beregovoi terrane has predominantly southwardvergent imbricate thrust fan structure (Figs. 4 and 6). This terrane consists of metamorphic rocks, volcaniclastic and basalt-chert assemblages, turbidites with olistostrome units gradually transformed southward into broken formation and terrigenous mélange, and serpentinite mélange with ophiolite and metamorphic rock fragments (Nekrasov, 1976; Chekhov and Palandzhyan, 1995; Kemkin et al., 1996; Vishnevskaya et al., 1998; Silantyev et al., 2000).

The key area showing structure and evolution of the Beregovoi terrane is well-exposed in the Povorotny Cape area (Fig. 6). The relationship between different tectonic units is shown in Fig. 6 and has been discussed by Silantiev et al. (2000). Upper Jurassic to Early Cretaceous sedimentary rocks consist of varicolored bedded cherts and shales, tuffs and volcaniclastic sandstones. Most of the terrigenous rocks are of turbidite origin with slump folds and soft-sediment deformation structures, pointing to deposition on the island arc 

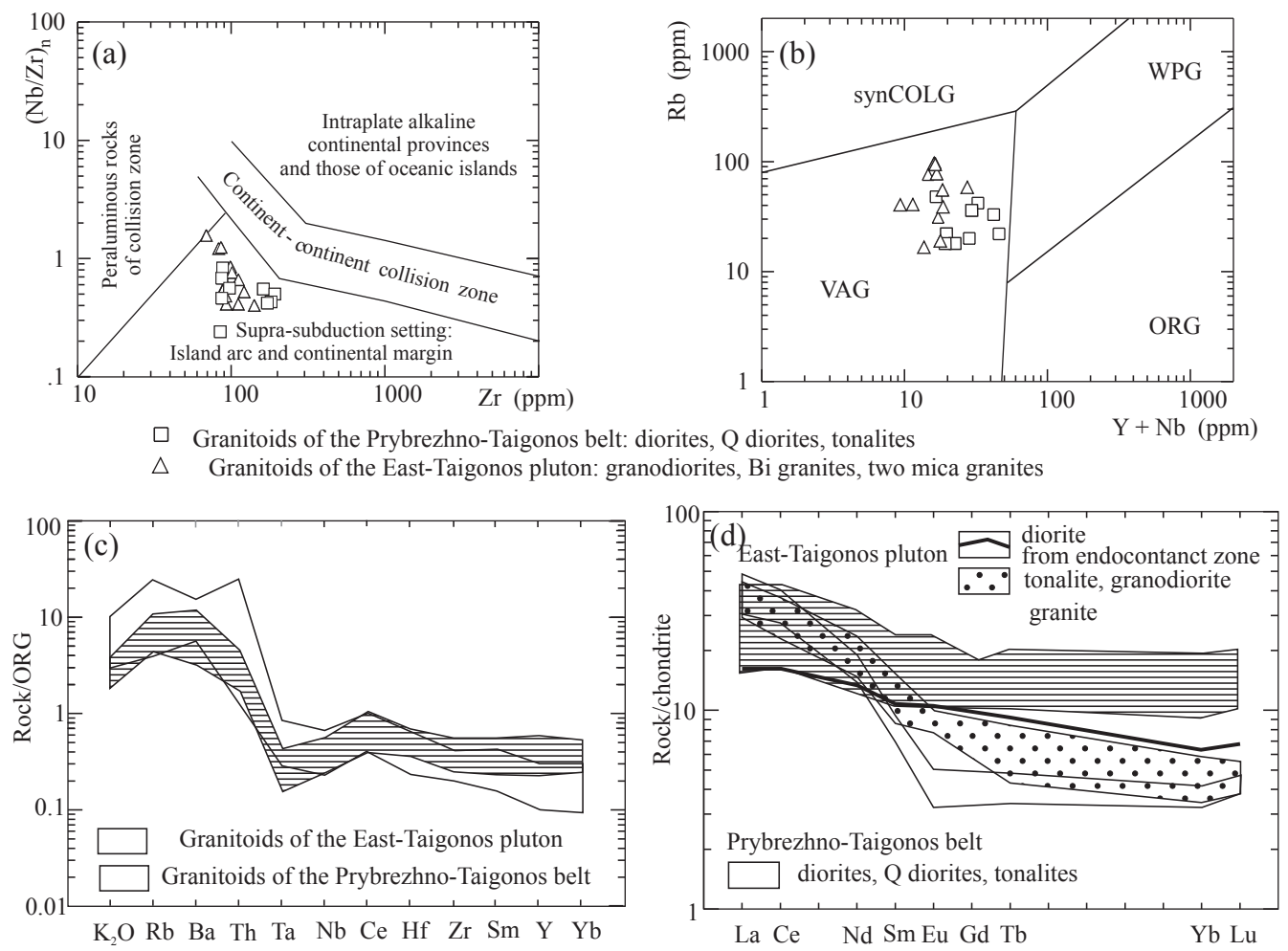

Fig. 5. Geochemical diagrams for granitoid intrusions of the East Taigonos pluton and Prybrezhno-Taigonos belt. A - Zr vs. $(\mathrm{Nb} / \mathrm{Zr})_{n}$ diagram after Thieblemont and Tegyey (1994); B - Rb vs. (Y+Nb) diagram after Pearce et al. (1984); C - ocean ridge granite (ORG) normalized diagram, normalization coefficients after Hofmann (1988); D - Chondrite-normalized REE patterns.

slope. Cherts were deposited in variable oceanic environments, but chemistry of cherts in the upper part of succession points to input of clastic material and approaching a continental margin (Konstantinovskaya, 1998).

The chemistry of magmatic units exposed in coherent tectonic slices and mélange blocks show juxtaposition of units formed in variable environments. According to Silantiev et al. (2000), trace and rare earth element distributions show the occurrence of N-MORB (normal mid ocean ridge basalts) and within-plate basalts, highly depleted and variably fractionated low-K tholeiites associated with the frontal parts of primitive island arcs, and boninites associated with ensimatic island arcs (Fig. 7). N-MORB typically have $\mathrm{Zr} / \mathrm{Y}$ ratios varying from 2.5 to 3.4 and a low $(\mathrm{La} / \mathrm{Yb})_{n}$ ratio varying from 0.66 to 0.85 , whereas within-plate basalts have a high $\mathrm{Zr} / \mathrm{Y}$ ratio (about 6.55$)$ and a $(\mathrm{La} / \mathrm{Yb})_{n}$ ratio varying from 5.4 to 12.3. Some tectonic slices in the the lower part of the Kingiveem unit contain a deformed dyke complex overlain by the volcanic and clastic rock unit, whereas serpentinite mélanges contain blocks of sheeted dykes, ultramafic rocks, gabbro, clastics, and cherts. Study of textures and mineral composition of ultramafic rocks also show that spinel lherzolites were formed close to mid-oceanic ridge, whereas the spinel $\mathrm{Cr}$ content in the spinel harzburgite is typical for supra-subduction peridotites (Bazulev et al., 2000).
Granitoid intrusions that cut the Lagerny unit are represented by small gabbro-diorite and diorite-tonalitegranodiorite plutons and commonly referred to as granitoids of the Prybrezhno-Taigonos belt. As well as those from the East Taigonos belt, granitoids of the Prybrezhno-Taigonos belt have $\mathrm{ASI}<1.1$ and belong to I-type granites or Mtype granites in the Pitcher $(1987,1993)$ classification (Appendix 1, see: http://www.stephan-mueller-spec-publ-ser. net/4/273/2009/smsps-4-273-2009-supplement.pdf). According to $\mathrm{Zr}$ versus $(\mathrm{Nb} / \mathrm{Zr})_{n}$ variations they are similar to granites from a supra-subduction setting (Fig. 5a). On the ORG-normalized diagrams they show LILE enrichment and HFSE depletion, $\mathrm{Ta}$ and $\mathrm{Nb}$ depletion relative to other HFSE (Fig. 5c), and they occupy the VAG field on the $\mathrm{Rb}-\mathrm{Y}+\mathrm{Nb}$ diagram (Fig. 5b) (Luchitskaya, 2001). The chondritenormalized REE patterns are less enriched in LREE than those of East-Taigonos pluton (Fig. 5d). ${ }^{40} \mathrm{Ar} /{ }^{39} \mathrm{Ar}$ ages of biotite from granodiorite and hornblende from gabbro are 101.1 \pm 0.4 and $103.5 \pm 1.9 \mathrm{Ma}$, respectively (Bondarenko et al., 1999). U-Pb SHRIMP zircon dating shows that zircon crystallization in the granitoids occurred between $105.5 \pm 0.9$ and 106.5 $\pm 0.9 \mathrm{Ma}$ (Hourigan, 2003; Luchitskaya et al., 2003).

Rock composition and juxtaposing of units formed in different tectonic environments within the Central Taigonos and Beregovoi terranes implies a complicated evolution of this 

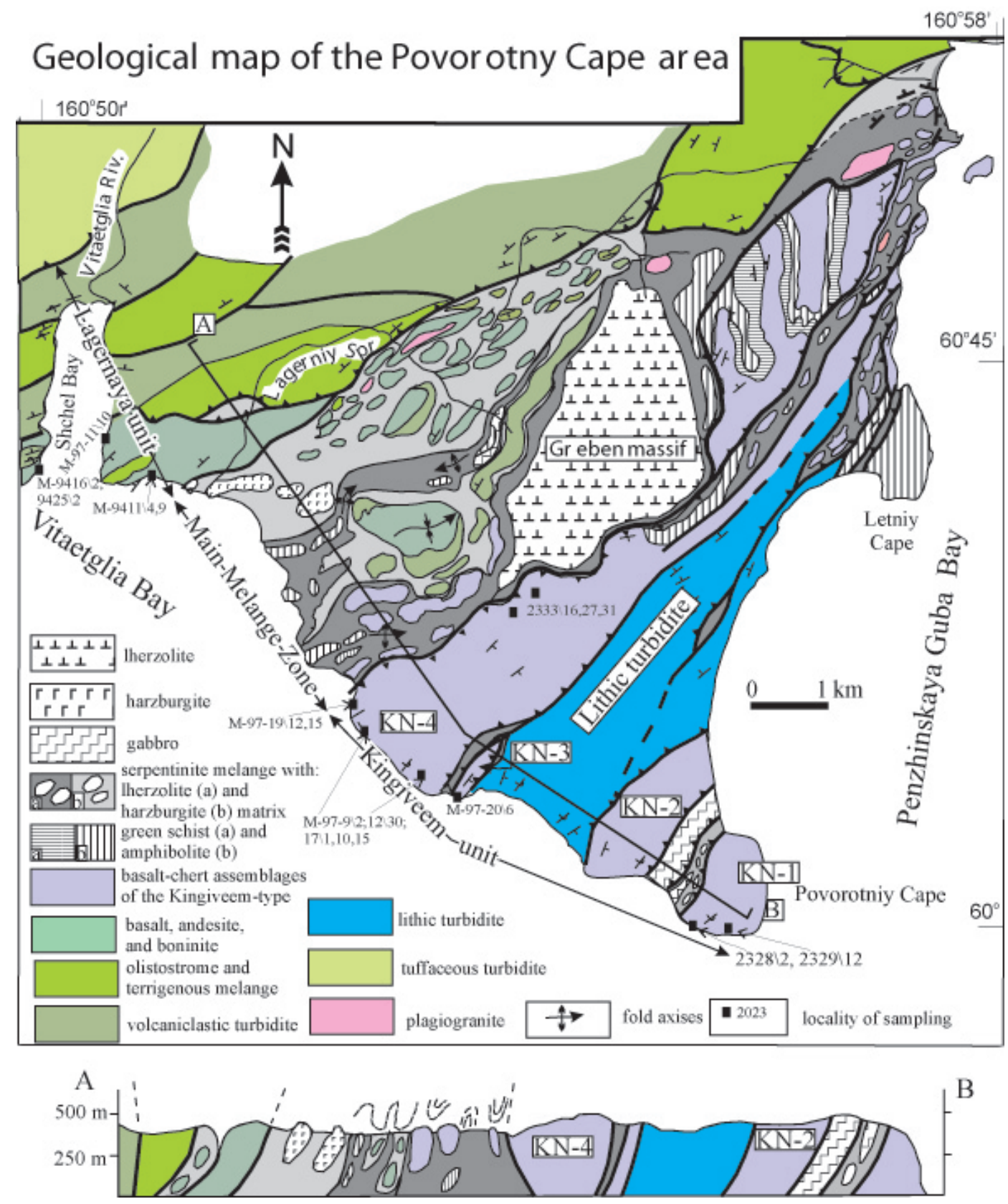

Fig. 6. Geological map and cross-section of the Povorotny Cape area (after Silantiev et al., 2000, simplified).

segment of the Uda-Murgal arc with large-scale horizontal displacement. ${ }^{40} \mathrm{Ar} /{ }^{39} \mathrm{Ar}$ dating of subduction-related amphibolites yielded ages which varied from $139 \pm 7.1$ (wholerock) to 109.6 \pm 4.1 (amphibole) Ma (Bondarenko et al., 1999).

The complicated tectonic history of the Taigonos segment is also inferred from our study of its structural evolution. Strike-slip faults of east-northeast trend are the predominant structural style of the Central Taigonos terrane. Both sinistral and dextral displacements are recognized, but sinistral displacements are younger than the dextral. In the Beregovoi terrane most widespread structures are ductile shear zones with sinistral and thrust displacement. Regional-scale thrusts cut metamorphic rocks with sinistral shear zones and seem to be younger than the latter. Formation of these faults in both terranes is associated with the main deformational event, close in age to the granite intrusion at ca. 97-105 Ma. Ductile shear zones are cut by brittle sinistral strike-slip faults and conjugated fractures that were formed in a stress field very similar to that which dominated during the formation 

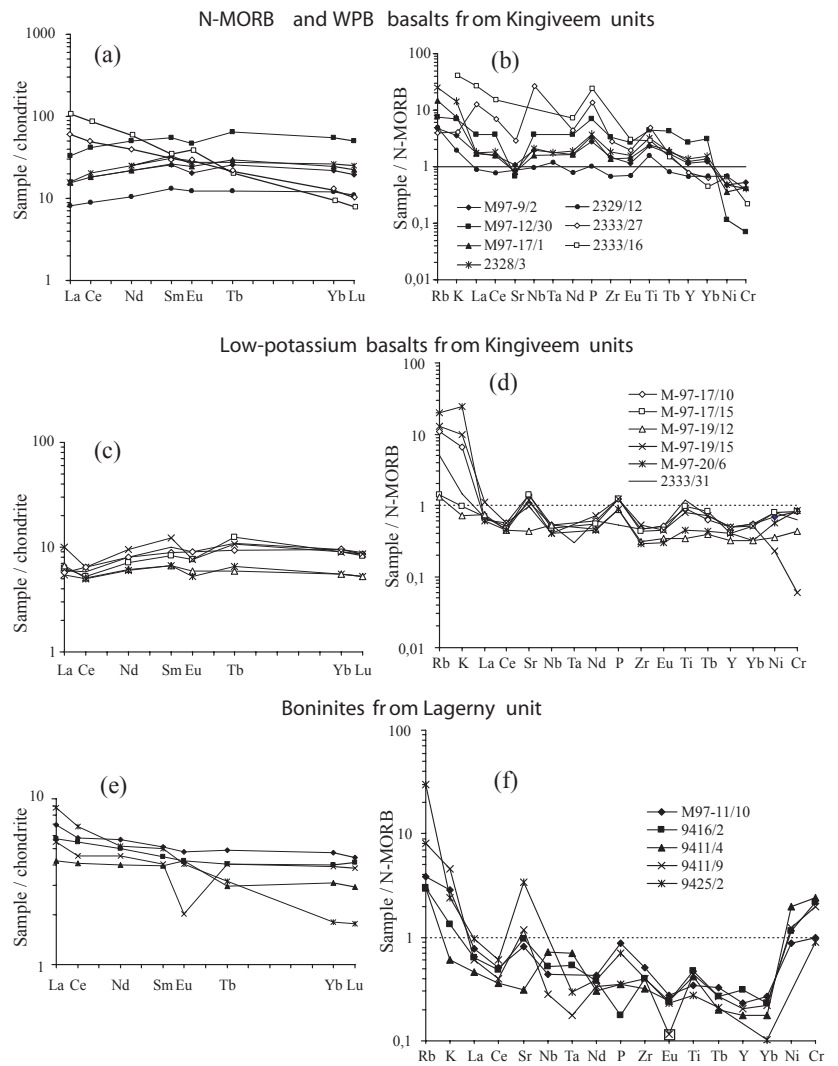

Fig. 7. Chondrite- and N-MORB-normalized diagrams for volcanic rocks of the Povorotny Cape area, normalization coefficients after Hofmann (1988). A, B - N-MORB and WPB basalts from Kingiveem unit; C, D - Low-potassium basalts from Kingiveem unit; E, F - Boninites from Lagernaya unit.

of the shear zones. Several shear zones contain slickenlines with normal sense of shearing pointing to a late extension probably related to orogenic collapse. The youngest (Cenozoic) tectonic activity is represented by northwest-trending strike-slip faults.

\subsection{Penzhina-Anadyr segment}

In a long belt from the northern shoreline of the Penzhina Bay up to middle course of the Anadyr River there are spatially separated outcrops of the Upper Jurassic-Lower Cretaceous succession that are overlapped by volcanic and sedimentary rocks of OCVB, the Penzhina forearc basin and Cenozoic sedimentary cover (Fig. 3). Tectonic slices of the Ganychalan and Ust-Belaya terranes contain oceanic crust rocks affected by subduction-related metamorphism in Early Carboniferous (Sokolov and Byalobzheskii, 1996). These slices partly form the basement of the Uda-Murgal arc and its forearc basin. In this region three facial zones are recognized in the Upper Jurassic-Lower Cretaceous succession.

The northern zone consists of volcanic and sedimentary rocks (Fig. 8) with a predominance of basalts and andesites,
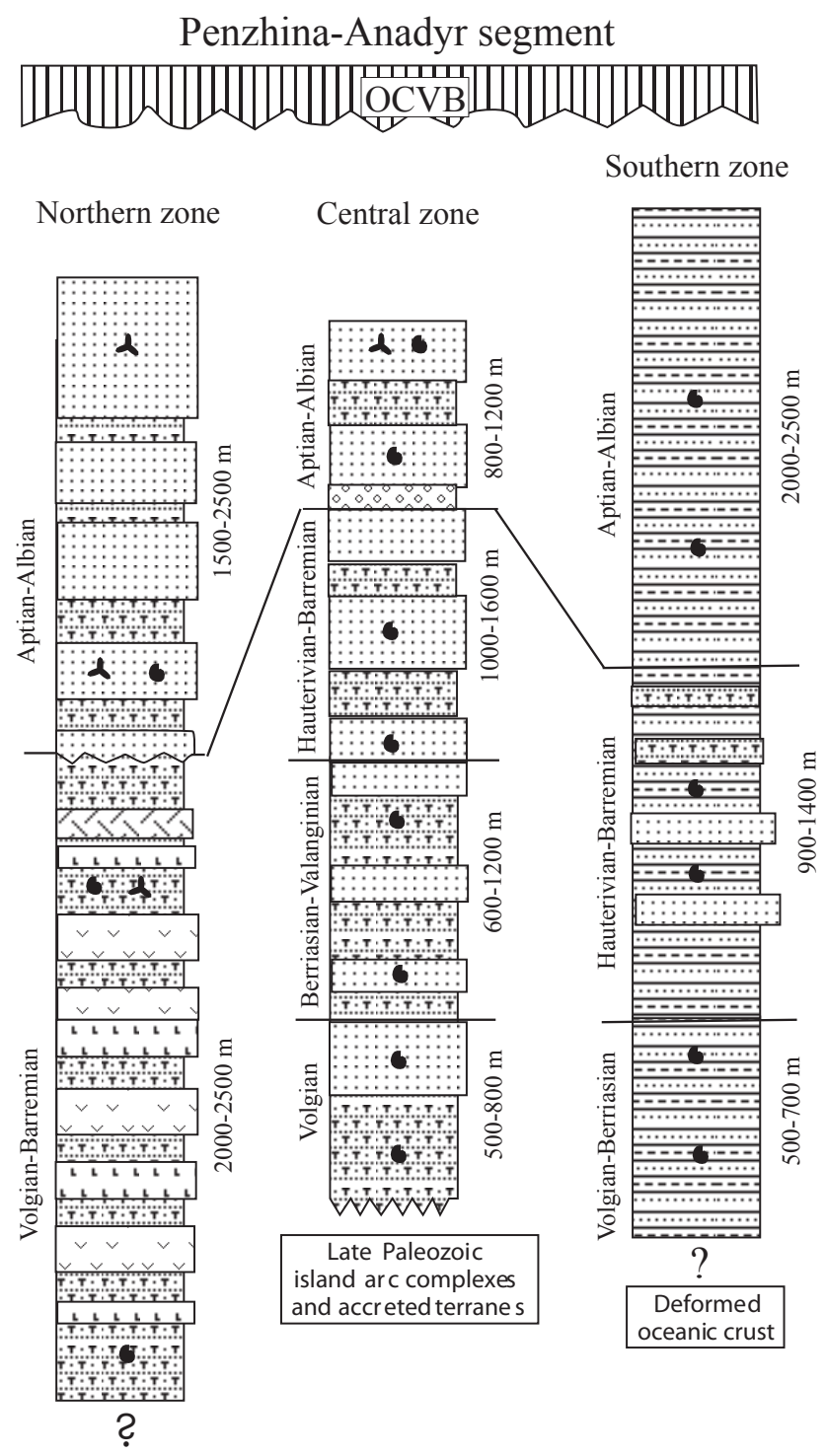

Fig. 8. Stratigraphic sections or the Penzhina-Anadyr segment. See legend in Fig. 2.

tuffs, tuff breccias, and coarse- to fine-grained volcaniclastic rocks. Volcanics are of calc-alkaline composition (Filatova, 1988). They are cut by granitoid intrusions with K-Ar wholerock ages of ca. $105 \mathrm{Ma}$ and $81 \mathrm{Ma}$ (Filatova, 1988; Belyi, 1994). This zone is interpreted as a volcanic part of the island arc.

The central zone consists of coarse- to fine-grained terrigenous rocks, tuffs and tuff breccias (Fig. 8). They unconformably overlie more ancient Paleozoic and Mesozoic rock units. In some stratigraphic sections, units contain hiatuses and conglomerates with reworked fauna of Paleozoic, Berriasian, and Valanginian age (Ivanov and Pohialaynen, 1973; Sokolov, 1992). This succession was deposited in the UdaMurgal forearc basin. 
The southern zone has been studied by the authors in the Penzhina River area. Sokolov (1992) recognized the Ainyn, Upupkin and Kuyul terranes (Fig. 3). These terranes accreted to the Asian continental margin at the end of Early Cretaceous (Sokolov, 1992) and are unconformably overlapped by post-accretional shallow-marine terrigenous sediments with late Albian fauna at the base (Ivanov and Pohialaynen, 1973; Alekseev, 1981).

Lower Cretaceous terrigenous rocks of the Upupkin terrane are represented by sandstones, siltstones and shales with conglomerate interbeds including reworked Late Jurassic fauna. In the north-western part of the terrane, the Hauterivian sequence contains approximately isometric bodies of sedimentary" serpentinites (Sokolov et al., 2000). They consist of a mixture of serpentinite, serpentinised ultramafic rocks, serpentinite-clastic breccia, conglomerate, sandstone and shale. Turbidites are recognized as well. These rocks were probably formed after a serpentinite diapir reached the submarine surface, followed by erosion and deposition of proximal (slumps) to distal (serpentinite-clastic turbidite) facies (Sokolov et al., 2000).

The Ainyn terrane consists of a thick terrigenous flysch unit (Fig. 8) (Ivanov and Pohialaynen, 1973; Alekseev, 1981). Turbidite with rare tuff interbeds predominates. Berriasian-Valanginian sandstones contain detrital grains of metamorphic and granite quartz, feldspars, granitoids, diorites, mica-chlorite schists, and mafic rocks. The observed heavy minerals are zircon, tourmaline, apatite, with lesser amount of the garnet and epidote group minerals (Tuchkova et al., 1999). Hauterivian-Aptian sandstones consist of mainly volcanic fragments. The content of magmatic quartz increases upward in the section. Heavy minerals are uniform and consist of pyroxene, magnetite, ilmenite with rare chromite (Tuchkova et al., 1999).

The Kuyul ophiolite terrane contains three types of sedimentary and volcanic rock successions (Grigoriev et al., 1995; Sokolov et al., 1996). The first type consists of Bathonian-Lower Tithonian oceanic basalts and cherts. The second type consists of Late Bathonian-Tithonian volcanic rocks of supra-subductional origin (Khanchuk et al., 1990). The third type succession consists in the lower part of layered red shaly cherts and cherty shales with Callovian-Early Tithonian radiolaria. In the upper part predominant rocks are siltstone, shale, and volcaniclastic sandstone with submarine slump units containing fragments of variable cherts, tuff sandstones, and limestone concretions. Chert fragments contain Late Triassic radiolaria, whereas shales host the Tithonian-Early Valanginian Buchia. The rocks are highly deformed and are transformed into terrigenous mélange. Deposition occurred in deep-water trench or at the base of accretion prism.

Three deformational events have been identified in the study area (Khudoley and Sokolov, 1998). The first event folds and shear zones are only recognized in metamorphic rocks of the Ganychalan terrane and are assumed to be Early
Carboniferous in age. The second event is recorded by structures that are imbricate fans of thrusts and folds with southeast vergence, broken formation and serpentinite mélange. These are Latest Jurassic to Early Cretaceous (Early Albian) and occur throughout the study area. During this event, thrusting was accompanied by dextral strike-slip faulting. The third deformational event is characterized by significant sinistral strike-slip displacements. The age of the sinistral strike-slip faults is interpreted to be Late Cretaceous to Cenozoic.

\subsection{Pekulney segment}

Upper Jurassic-Lower Cretaceous rocks are represented by volcanic-plutonic, chert-basalt, chert-terrigenous-basalt, terrigenous and picrite-basalt assemblages (Figs. 9 and 10).

Volcanic-plutonic assemblage contains variable Tithonian to Valanginian volcanic and sedimentary rocks as well as numerous dykes and plutonic rocks. Basement of the assemblage consists of tectonically juxtaposed magmatic and metamorphic rocks of Precambrian, Late Paleozoic and Mesozoic age (Nekrasov and Lyapunov, 1987; Zhulanova, 1990; Morozov, 2001).

Basalt and andesite-basalt predominate among the volcanic rocks. Andesite, rhyolite and dacite are less common and are located mainly in the upper part of succession. Acidic volcanics are typically sub-volcanic facies and tuffs.

The sedimentary succession contains tuffaceous and lithic conglomerates, breccias, sandstones, siltstones and rare shales. Detrital fragments are volcanics of variable composition and metamorphic degree, including tuffaceous sedimentary rocks, graphite schists with cordierite, andalusite or garnet, and biotite-hornblende plagiogneiss. Fragments of gabbro-diorite, diorite, tonalite and granite are also common (Morozov, 2001).

Plutonic rocks are represented by acidic sub-volcanics, observed as dyke swarms varying in composition from basalt to rhyolite, as well as by plagiogranite and amphibole gabbro intrusions (Morozov, 2001).

The chemistry of the magmatic rocks suggest formation in a supra-subduction setting (Morozov, 2001). Depleted tholeiite, peraluminous tholeiite, and calc-alkaline volcanic rocks are widespread. Highly titanium-rich supra-subduction volcanics are of local distribution. Some volcanics are shoshonite, whereas some dykes are close in composition to boninite-marianite basalt series.

Chert-terrigenous-basalt assemblage (Fig. 10) consists of basalt, agglomerate, with regular and lenticular interbeds of black cherty shales, siltstone, and, rarely, siliceous tuff. Although radiolaria found in succession are recrystallized and poorly preserved, there are Late BerriasianEarly Valanginian Buchia (Morozov, 2001). The chemical composition data shows that the basalts studied are close to MORB tholeiites. However, they are enriched in $\mathrm{P}, \mathrm{La}, \mathrm{Rb}$, $\mathrm{Ba}, \mathrm{K}, \mathrm{Sr}$, and slightly depleted in $\mathrm{Ta}$ and $\mathrm{Nb}$, indicating an 
affinity to a supra-subduction setting (Morozov, 2001). The assemblage is interpreted as fragments of backarc basin behind a convergent plate boundary.

Chert-volcanic assemblage forms a number of slices composed of sheeted diabase dykes, basalts, pillow-lava, and overlapping platy cherts, siliceous tuff, siltstone and shale (Fig. 10). Radiolaria in cherts yields a Bajocian to Early Cretaceous age (Morozov, 2001, 2000) whereas siltstones contain Buchia of Late Valanginian age. The chemistry of volcanics is close to that of N-MORB, E-MORB (enriched mid ocean ridge basalts), and intraplate basalts. Locally rocks of this assemblage are metamorphosed up to greenschist, blueschist, and epidote-amphibolite grade.

Spatially close to rocks of the chert-volcanic assemblage are slices with Early Cretaceous cherts, tuffs, terrigenous rocks, and olistostrome units. Among olistoliths there are oceanic volcanics and cherts, island arc volcanics, tuffs, and metamorphic rocks. All of these rocks form a part of an accretionary prism (Morozov, 2001).

The Picrite-basalt assemblage is associated with serpentinite mélange units. It contains picrite, picrite-basalts, basalts, volcanic breccia occasionally interbedded with volcaniclastic or tuffaceous sandstones. Numerous sub-volcanic and hypabyssal mafic and ultramafic intrusions are related to the volcanic rocks. Chemistry of the assemblage points to its formation as a result of intra-arc rifting (Morozov, 2001).

Post-accretionary rock unit consists of flysch-like tuff and terrigenous rocks. Age of its basal beds gradually changes from Hauterivian-Barremian in the north to BarremianAptian in the south.

\subsection{Chukotka segment}

The Chukotka segment of the Uda-Murgal arc contains the Kanchalan, Ushkanegorsk, and Zolotogorsk terranes (Morozov, 2001). Exposures of Paleozoic and Mesozoic rocks are rare and spatially separated by unconformably overlapping Upper Cretaceous volcanic and sedimentary rocks (OCVB) and Tertiary sediments.

Upper Paleozoic variably metamorphosed volcanic and sedimentary rocks were found only in the Kanchalan terrane. There the sedimentary succession consists of carbonate and terrigenous rocks. Volcanics range in composition from trachyandesite to trachyrhyolite. They form a unique succession with chemistry close to that of high-potassium calcalkaline volcanics of the Andean margin and mature island arcs (Morozov, 2001).

Upper Jurassic-Lower Cretaceous (TithonianValanginian) complex consists of tuffs and terrigenous rocks and sub-volcanics. Rocks are highly deformed and cut and often metamorphosed by Early and Late Cretaceous granitoids.

Three types of succession are recognized among the Upper Jurassic-Lower Cretaceous rocks: (1) Lava, tuff breccia, tuffs of mafic, intermediate and acidic composition, and sedimentary rocks. Sedimentary rocks include siltstones, shales and coal-bearing shales with thin parallel and cross bedding with numerous flora remnants. These rocks were deposited in lacustrine environments. The tectonic setting of this succession is interpreted as being the volcanic part of an island arc. (2) Flysch-like unit with alternation of volcaniclastic and lithic sandstones, siltstones and shales with proximal and distal facies of island arc slope and rise. (3) Thin alternating cherts, cherty and limy siltstones, shales and tuffaceous sandstones. The high portion of hemipelagic facies suggests deposition of this unit in a forearc setting (Morozov, 2001).

Early Cretaceous intrusions are gabbro-plagiogranite, diorite and granite. Whole-rock K-Ar dating of the external part of a plagiogranite pluton yielded a $120 \pm 7 \mathrm{Ma}$ age (Morozov, 2001). Granite often contains xenoliths of ultramafic and mafic rocks. Interpretation of their chemical composition suggests that the granite intrusions were formed in a volcanic island arc tectonic setting (Morozov, 2001).

\section{Discussion: tectonic interpretation and reconstruction of the Uda-Murgal arc}

\subsection{Reconstruction of the Uda-Murgal arc}

The Western Koryak fold and thrust belt includes Paleozoic and Mesozoic assemblages that were formed in suprasubduction geodynamic setting. The data presented on structure and composition of Upper Jurassic-Lower Cretaceous rocks make it possible to reconstruct the ancient convergent margin of the Asian continent with the Uda-Murgal arc located parallel to this margin (Fig. 11). The region had a complicated structure and consisted of several segments that differ from each other by the type and composition of basement, volcanism, deposition and a lateral set of structures formed in the continent-ocean transition zone. The difference in composition of the segments as well as the lack of detailed studies resulted in a diversity of ideas regarding the age and tectonic nature of the Uda-Murgal arc (e.g. Nekrasov, 1976; Parfenov, 1984; Filatova, 1988; Sokolov, 1992; Nokleberg et al., 1994).

In the Uda-Piyagin segment only the volcanic part of the island arc and a part of backarc basin are recognized. Frontal structures of the island arc are covered by the water and sediments of the Sea of Okhotsk. The island arc assemblages rest on a heterogeneous basement that includes Late PaleozoicEarly Mesozoic Koni-Taigonos island arc, Siberian craton, Verkhoyansk Complex, and Okhotsk cratonic terrane. As the restored island arc does not contain marine sediments in a backarc basin, volcanics were located on the margin of continent and therefore are interpreted to have formed an Andeantype continental margin (Parfenov, 1984). The Late JurassicEarly Cretaceous convergent boundary was oblique to more ancient structures of the Asian continent. 


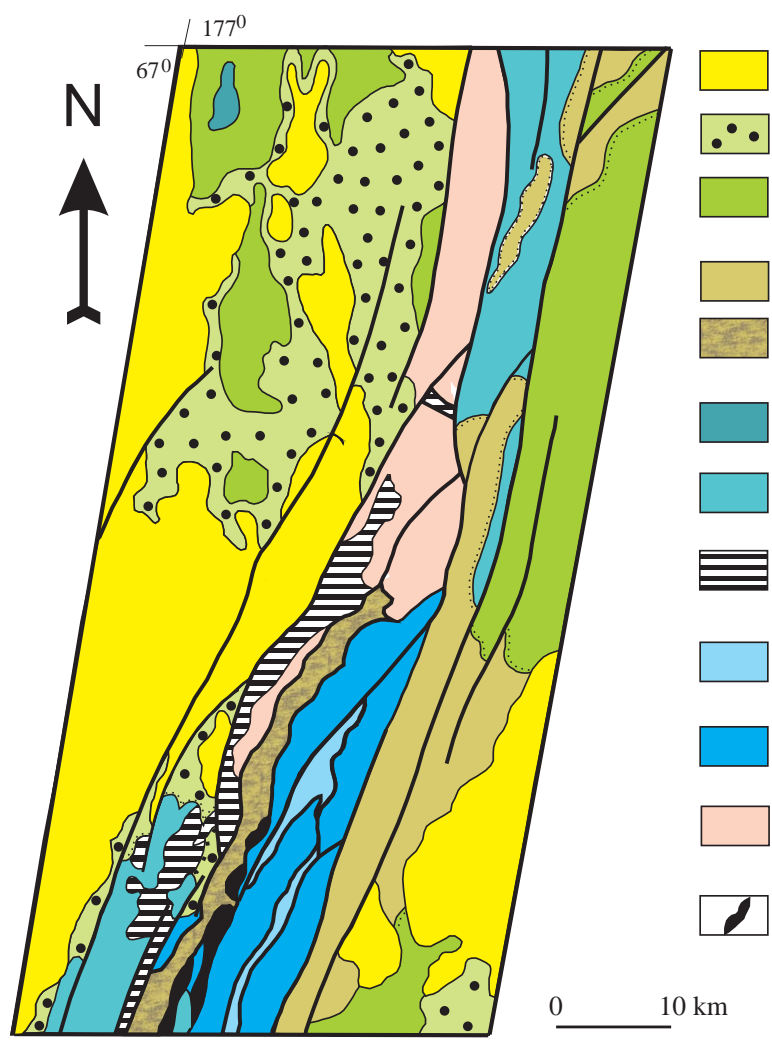

Paleocene-Miocene basalt and clastic rocks

Senonian-Danian coal-bearing molasse

Late Albian-Late Cretaceous volcanic, tuff and clastic rocks of Okhotsk-Chukotka volcanic belt

Hauterivian-Albian turbidite

Hauterivian picrite, basalt and sedimentary rocks (intra-arc spreading complex)

Berriasian-Valanginian basalt, cherty-tuffite and siltstone (back-arc spreading complex)

Late Jurassic-Early Cretaceous volcanic, tuff and clastic rocks (island arc complex)

Late Jurassic-Early Cretaceous plagiogranite and gabbro (island arc complex)

Berriassian-Valanginian terrigenous accretionary melange

Middle Jurassic-Early Cretaceous pillow-basalt, chert and sheeted-dike (ocean spreading complex)

basement of Middle Jurassic-Early Cretaceous island arc complex - gabbro, granite and metamorphic rocks

\section{garnet-bearing ultrabasic rock} and amphibolite

Fig. 9. Simplified geological map of the Pekulney Range.

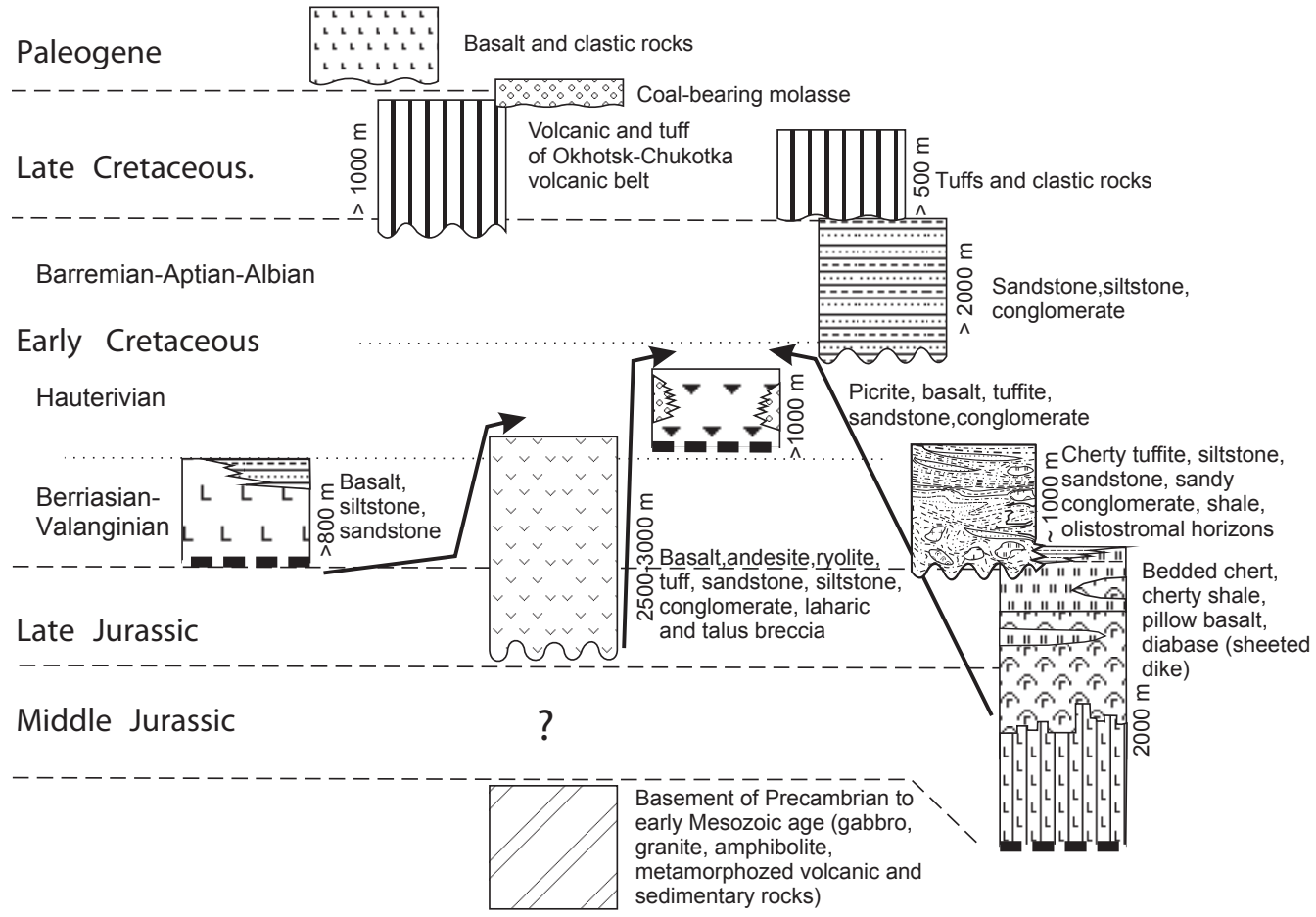

Fig. 10. Tectono-stratigraphic complexes of the Pekulney segment. See legend on Fig. 2. 


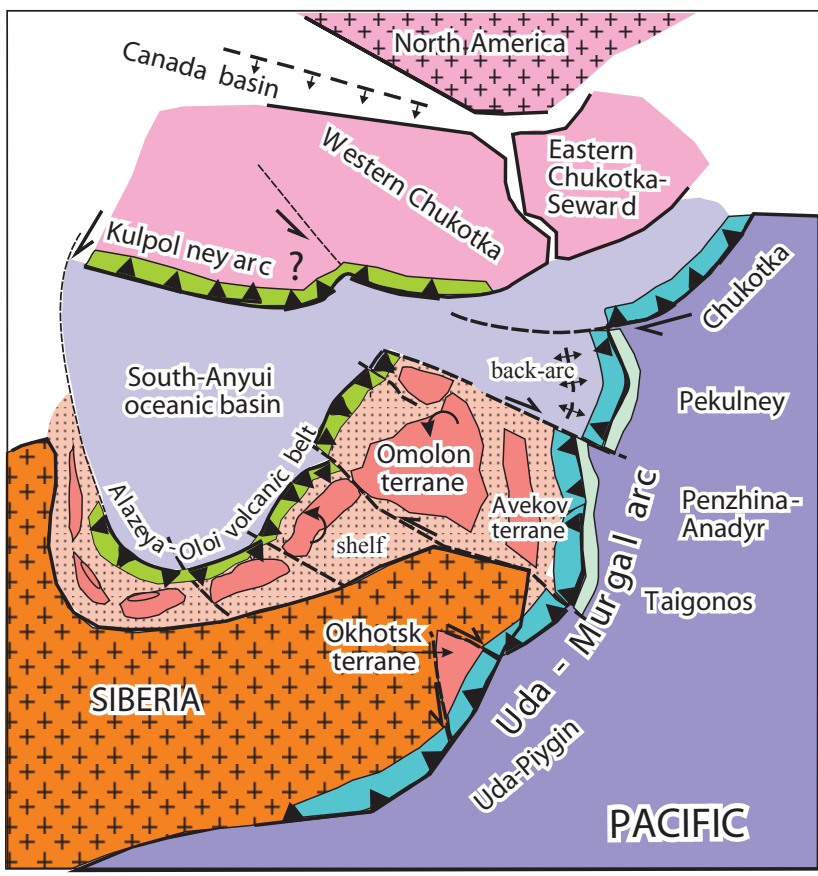

Uda-Murgal convergent margin: volcanic arc prism

Fig. 11. Late Jurassic-Early Cretaceous reconstruction of the UdaMurgal convergent margin and adjacent area.

In the Taigonos segment, the axial volcanic zone of the Uda-Murgal arc is preserved in the Central Taigonos terrane, while the Beregovoi terrane preserves the accretionary prism (Fig. 12). Volcanic rocks of the Uda-Murgal arc overlap the more ancient Koni-Taigonos island arc. Volcanism and deposition occurred in a shallow-marine to continental environments along the margin of the Asian continent.

The forearc succession is represented by volcaniclastic terrigenous rocks including turbidites, with interbeds of tuffs and pyroclastics. Mafic volcanics predominate in the southern part, whereas intermediate and acidic volcanics are typical for its northern part. During the final stages of volcanic activity large stratovolcanoes predominated. Intrusion of a large granite pluton that cut rock units in the forearc and accretionary prism marked the termination of volcanic activity along this segment.

In the Penzhina-Anadyr segment, the northern facial zone of the Upper Jurassic-Lower Cretaceous volcanic and sedimentary rocks is a typical island arc complex (Parfenov, 1984; Filatova, 1988). Probably, it represents only the axial volcanic zone of an island arc. Marine flysch-like rocks are widespread in the upper course of the Penzhina River and may represent sedimentary fill of a backarc basin (Filatova, 1988) that separated the volcanic island arc from the Omolon massif. To the northwest these are replaced by thin Upper Jurassic rock units that were deposited in shallow- marine environments along the east margin of the Omolon massif, whereas Lower Cretaceous rock units are of continental origin. Therefore a mature ensialic island arc occurred in the Penzhina-Anadyr segment. In our model the gradually shoaling marginal sea with thinned continental crust in the back of the island arc was opening northward and connected with the South Anyui oceanic basin (Fig. 11).

The central zone succession only contains marine to deepmarine facies (Migovich, 1972; Ivanov and Pohialaynen, 1973; Sokolov, 1992). These are predominantly terrigenous in composition with rare pyroclastics and volcanics. Local erosion surfaces and units with reworked ancient fauna are typical. This region has been interpreted as resulting from deposition in a basin located between frontal nonvolcanic and back volcanic arcs (Nekrasov, 1976; Sokolov, 1992). If this model is correct, then the frontal arc consists of Ganychalan, Upupkin and Ust-Belaya allochthonous terranes (Fig. 3). However, variability in stratigraphy of local sections inside the central zone shows that deposition occurred in different basins located in a wide forearc part of the island arc. The most outer basin was the Upupkin terrane succession. Some serpentinite mélange units have structural features typical for mélanges of diapir origin (Khudoley and Sokolov, 1998). If so, in this part of forearc serpentinite diapirs were probably formed similarly to those in the modern Idzu-Bonin and Mariana convergent margin (Fryer, 1992; Lagabrielle, 1992).

Turbidites of the Ainyn terrane are interpreted as deposited at the outer rise of an island arc and an accretionary prism that included accreted units of the Kuyul ophiolite terrane. The latter contains fragments of oceanic crust represented by ophiolite, basalt-chert and basalt-carbonate-chert assemblages, supra-subduction ophiolite and ensimatic island arc complex, and trench sediments with olistostrome units. Most of them are Middle (Bathonian) to Late Jurassic in age, but Late Triassic-Middle Jurassic (Bajocian) blocks of the oceanic crust have been reported as well (Grigoriev et al., 1995; Sokolov, 1996).

Thus, in the Penzhina-Anadyr segment (Fig. 12) backarc basin, axial volcanic zone, forearc, and accretionary prism of the Uda-Murgal arc, along with accreted oceanic complexes are restored. Basement of the axial volcanic zone is not exposed, whereas forearc basement consists of accreted units of Upper Paleozoic-Lower Mesozoic island arc, shelf, and forearc complexes, and Early Paleozoic ophiolites formed oceanic lithosphere of Paleo-Pacific (Sokolov, 1992; Sokolov et al., 1997).

Island arc complexes of the Penzhina-Anadyr segment were located along the margin of the continent. Behind the Uda-Murgal arc there was an epicontinental marginal sea. The margin of the Asian continent was represented by the Omolon superterrane (Parfenov et al., 1993) and accreted Late Paleozoic-Early Mesozoic Koni-Taigonos island arc and terranes of the Penzhina area (Khudoley and Sokolov, 1998). 
Late Jurassic-Early Cretaceous reconstruction of the Uda-Murgal convergent margin
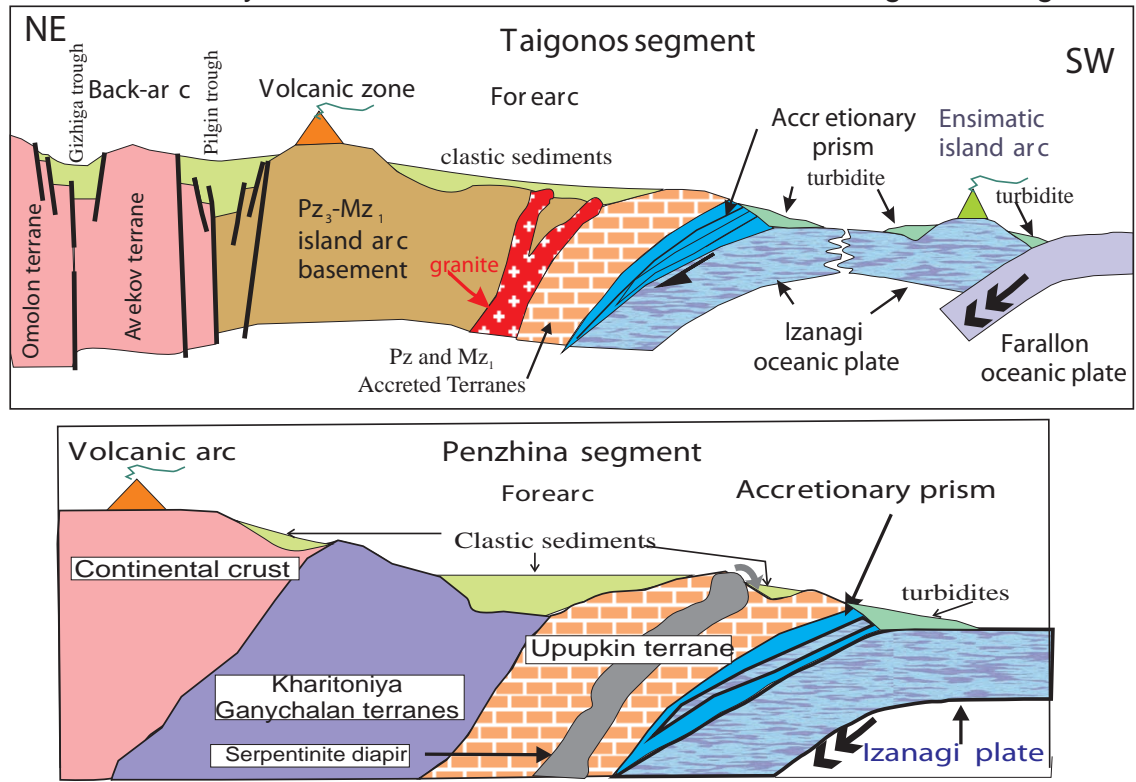

Fig. 12. Late Jurassic-Early Cretaceous reconstruction of the Uda-Murgal arc.

Early models suggested that the ophiolites and basalt-chert assemblages of the Pekulney Range were formed in a rift (Markov and Nekrasov, 1979). Modern interpretation of these complexes are that they were formed in the continentocean transition zone (Parfenov, 1984; Sokolov, 1992; Parfenov et al., 1993). More details on the geology and the tectonic evolution of ophiolites and basalt-chert assemblages of the Pekulney Range were presented by Morozov (2001).

In the Pekulney segment, in the oceanward direction from the backarc basin with oceanic crust, are an axial volcanic zone, forearc and accretionary prism with offscraped fragments of oceanic crust and Lower Cretaceous continental slope deposits with olistostromes (Fig. 13).

In the axial volcanic zone of the island arc, volcanism and sedimentation occurred in continental to shallow marine environments in areas with highly differentiated relief. Some sedimentary rocks contain ripple marks, low-angle cross bedding, broken shells and other evidence of shallow marine to near shore depositional environments. A portion of these sedimentary rocks were formed as a result of mud or pyroclastic avalanches and gravity mass flows having moved from the base of a volcano or near the shoreline zone of the forearc basin.

Formation of an oceanic chert-volcanic assemblage occurred in a topographically low mid oceanic ridge with a high spreading rate. Minor tuffaceous terrigenous rocks in the upper part of succession imply motion of the plate in Late Valanginian closer to the convergent boundary. In the Pekulney segment, island arc complexes overlie the heterogeneous basement consisting of fragments of lower continental crust and oceanic lithosphere (Morozov, 2001).
Pekulney segment

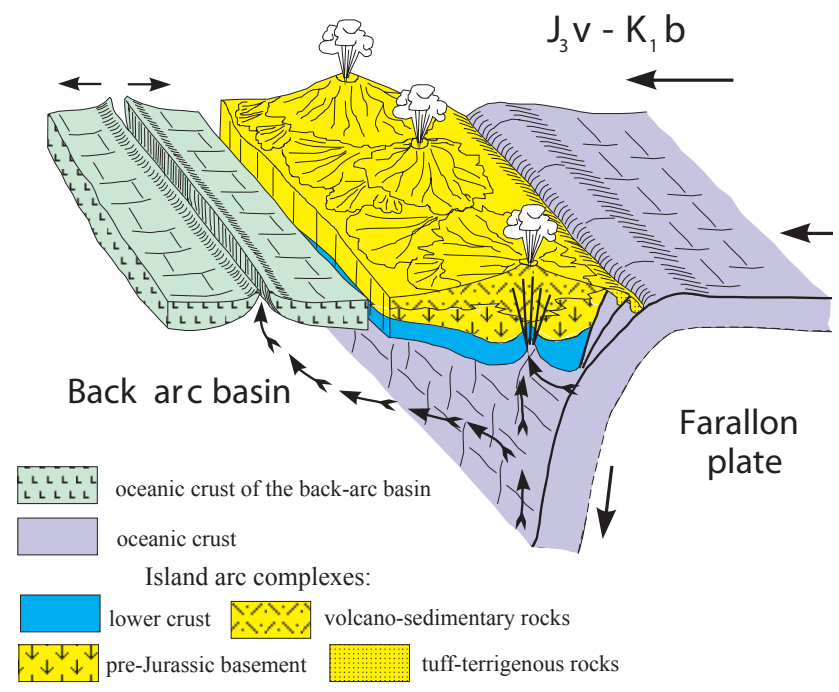

Fig. 13. Late Jurassic-Berriasian reconstruction of the Pekulney segment of the Uda-Murgal arc.

The Chukotka segment of the island arc had basement which varied in composition from an ensimatic to ensialic arc (Morozov, 2001). This forms a sub-latitudinal extension of the convergent margin and also separated the Mesopacific from the eastern part of South-Anyui basin and related structures of Chukotka microcontinent (Fig. 11). In this segment, island arc volcanic activity was terminated by the Aptian and was not as extensive as in other segments of the Uda-Murgal 
arc. These other segments probably resulted from oblique subduction of Mesopacific oceanic crust beneath Chukotka. Possibly, the Chukotka segment should be identified as a single island arc. We propose that it and the Uda-Murgal arc belong to the same convergent boundary between the Asian continent and oceanic plates of the northern Pacific basin.

\subsection{Plate tectonic reconstructions}

Juxtaposition of rock units of variable tectonic origin and the occurrence of numerous thrusts and strike-slip faults point to significant displacement of tectonic units that combined in the Uda-Murgal arc. Available paleomagnetic data is not sufficient for detailed reconstruction of motions of all terranes, but gives a first-order approximation of the displacement magnitude and history.

In the first paleotectonic reconstructions (Zonenshain et al., 1987, 1991) all allochthonous terranes of Northeast Russia were assumed to be transported by the Kula plate. The following reconstructions were mainly based on the plate kinematics inferred by Engebretson et al. (1985). According to the available paleomagnetic and structural data (Sokolov et al., 1997; Khudoley and Sokolov, 1998) displacement of terranes in the Koryak-Kamchatka fold and thrust belt show reasonable fit with displacements of the Farallon and Pacific plates discussed by Engebretson et al. (1985).

New paleomagnetic data show that Triassic cherts of the Kingiveem unit of the Beregovoi terrane were deposited at $2.3^{\circ} \pm 3.2^{\circ}$ and Jurassic cherts were deposited about at $35^{\circ} \mathrm{N}$ (Bazhenov et al., 1999; Aleksutin et al., 2005). These paleolatitudes are significantly to the south of their current location and correspond with location of the Izanagi plate at those times.

The chemistry of the cherts implies that an oceanic plate gradually moved from the central part of the ocean toward a continental margin (Konstantinovskaya, 1998).

Paleomagnetic data from the oceanic crust fragments within the Kuyul ophiolite terrane point to their formation southward from their present location (Harbert et al., 2003). Unfortunately, there are no reliable data for the Middle-Late Jurassic basalts and cherts to recognize their relationship to the Izanagi or Farallon plates. However, oceanic complexes accreted to the northern part of the Koryak Upland were likely transported by the Farallon plate (Sokolov et al., 1997).

The existence of island arc complexes (Lagerny and Kingiveem units of the Beregovoi terrane) and suprasubductional ophiolites in the accretion prism suggest a preValanginian collision of ensimatic island arcs with the active continental margin represented by Uda-Murgal arc. As ensimatic island arc successions of Lagerny and Kingiveem units are separated by oceanic crust and plagiogranite and acidic volcanics were found in Lagerny unit but not Kingiveem unit, we interpret the Lagerny and Kingiveem units to represent different ensimatic arcs. According to paleomagnetic data, island-arc volcanics of the Lagerny unit were formed at $28.6^{\circ} \pm 7.8^{\circ} \mathrm{N}$ (Aleksutin et al., 2005). It looks most possible that these island arcs marked the boundary between the Izanagi and Farallon plates, that was probably of convergent nature (Sokolov et al., 1997; Bazhenov et al., 1999; Aleksutin et al., 2005).

\section{Conclusion}

A long belt of Upper Jurassic-Lower Cretaceous volcanic and sedimentary rocks formed along convergent margin of the Asian continent and the north-western Pacific is recognized from the Mongolo-Okhotsk fold and thrust belt in the south to the Chukotka Peninsula in the north.

In the Uda-Piyagin, Taigonos, and Penzhina-Anadyr segments island arc volcanics were erupted along an Andeantype margin of the Asian continent and/or mature island arc (Fig. 1). In the Pekulney and Chukotka segments, an island arc separated structures of the Meso-Pacific from the South-Anyui basin, which was a marginal sea or relicts of oceanic basin. In the inner part of the Pekulney segment a new backarc basin similar to modern Komandorsky basin was formed.

Acknowledgements. Research was supported by INTAS (project 96-1880), RFBR (project 05-05-65052, 08-05-00547), and FCP Scientific school grants.

\section{References}

Alekseev, E. S.: Kuyul serpentinite mélange and the structure of the Talovsk-Maynska Zone (Koryak Mountains), Geotectonics, 2, 68-78, 1981 (in Russian).

Aleksyutin, M. V., Sokolov, S. D., Morozov, O. L., and Harbert, W.: New paleomagnetic results from accretionary complexes of the Taigonos Peninsula and their paleotectonic implications, (translated from Geotektonika, 3, 38-52, 2005) Geotectonics, 39, 200 212, 2005.

Bazhenov, M. L., Aleksuytin, M. V., Bondarenko, G. Ye., and Sokolov, S. D.: Mesozoic paleomagnetism of the Taigonos Peninsula, the sea of Okhotsk: implications to kinematics of the continental and oceanic plates, Earth Planet. Sc. Lett., 173, 113127, 1999.

Bazylev, B. A., Silantyev, S. A., and Ganelin, A. V.: Different ultramafic types at Povorotny Cape ophiolite mélange, Taigonos Peninsula, NE Russia, GEOSCIENCE 2000, Conference Abstracts, University of Manchester, 25 pp., 2000.

Belyi, V. F.: Geology of the Okhotsk-Chukotka Volcanic Belt, NEISRI FEB RAS, Magadan, 76 pp., 1994 (in Russian).

Bogdanov, N. A. and Tilman, S. M.: Tectonics and geodynamics of North-East Russia (map and explanation text), ILSAN Press, Moscow, 54 pp., 1992 (in Russian).

Bondarenko, G. Ye., Morozov, O. L., Layer, P., and Minyuk, P. V.: New data on Ar-Ar isotope dating of magmatic and metamorphic rocks of the Taigonos Peninsyla (Northeast Russia), Reports RAS, 369(1), 79-82, 1999 (in Russian). 
Bondarenko, G. Ye., Morozov, O. L., Kravchenko-Berezhnoy, I. P., Khudoley, A. K., and Silantiev, S. A.: Tectonics of the Pylgin shear zone (Taigonos Peninsula, Northeast Russia), Russian Journal of the Earth Sciences, 2(1), 71-93, 2000 (in Russian).

Chappell, B. W. and White, A. J. R.: Granitoid types and their distribution in the Lachlan Fold Belt, southeastern Australia, Geological Society of America Memoirs, 159, 21-37, 1983.

Chekhov, A. D. and Palandzhyan, S. A.: Exotic terranes of Taigonos Peninsula, Northeastern Russia, International Conference On Arctic Margin, Proceeding, NEISRI, Magadan, 176-178, 1995.

Engebretson, D. C., Cox, A., and Gordon, R. G.: Relative motions between oceanic and continental plates in the Pacific basin, Geological Society of America, Special Paper, 206, 59 pp., 1985.

Filatova, N. I.: Peri-Oceanic volcanic belts, Moscow, Nedra, 262 pp., 1988 (in Russian).

Fujita, K. and Newberry, J. T.: Accretionary Terranes and Tectonic Evolution of Northeast Siberia, in: Accretion tectonics in the Circum-Pacific Regions, edited by: Hashimoto, M. and Yeda, S., Tokyo, TERRAPUB, 43-58, 1983.

Fryer, P.: A synthesis of leg 125 drilling of serpentinite seamounts on Mariana and Izu-Bonin forearcs, Proceedings of the Ocean Drilling Program, Scientific Results, 125, 593-614, 1992.

Golonka, J., Ross, M., and Scotese, C. R.: Phanerozoic paleogeographic and paleoclimatic modelling maps, in: Pangea: Global Environments and Resources, edited by: Embry, A. F., Beauchamp, B., and Glass, D., Canadian Society of Petroleum Geologists Memoir, 17, 1-47, 1994.

Grigoriev, V. N., Sokolov, S. D., Krylov, K. A., Golozubov, V. V., and Pralnikova, I. E.: Geodynamic typification of the Triassic-Jurassic volcanic-siliceous complexes in the Kuyul terrane (Koryak Highlands), Geotectonics, 29(3), 248-258, 1995 (in Russian).

Gromov, V. V., Lebedev, E. L., and Stavtsev, A. L.: Geological composition of the Uliya depression, Soviet Geology, 3, 21-29, 1980 (in Russian).

Harbert, W., Sokolov, S. Krylov, K., Alexutin, M., Grigoriev, V., and Heiphetz, A.: Reconnaissance Paleomagnetism of Late Triassic Blocks, Kuyul Region, Northern Kamchatka Peninsula, Russia, Tectonophysics, 361, 215-227, 2003.

Hofmann, A. W.: Chemical differentiation of the Earth. The relationship between mantle, continental crust and oceanic crust, Earth Planet. Sc. Lett., 90, 297-314, 1988.

Hourigan, J.: Mesozoic-Cenozoic tectonic and magmatic evolution of the northeast Russian margin, Ph.D. thesis, Stanford University, Stanford, California, 257 pp., 2003.

Ivanov, V. V. and Pohialaynen, V. P.: Cretaceous deposits of Southern part of Penzhin trough in relation to oil-gas productivity, in: On the problems of oil and gas productivity of North-Eastern USSR, Transactions SVKNII DVNC Ac. Sci. USSR, 49, 70-107, 1973 (in Russian).

Kemkin, I. V., Palandzhyan, S. A., and Chekhov, A. D.: Substantiation of the age of chert-volcanic complexes of the Povorotny Cape, Penzhina-Pekulney ofiolite belt (Northeast Asia), Geology of Pacific Ocean, 15(5), 69-79, 1996 (in Russian).

Khanchuk, A. I., Grigoriev, V. I., Golozubov, V. V., Govorov, G. I., Krylov, K. A., Kurnosov, V. I., Panchenko, I. V., Pralnikova, I. E., and Chudaev, O. V.: Kuyul Ophiolite Terrane, Vladivostok, Academy of Science, Far East Branch, 108 pp., 1990 (in Russian).
Khudoley, A. K. and Sokolov, S. D.: Structural evolution of the northeast Asia continental margin: An example from the western Koryak fold and thrust belt (northeast Russia), Geol. Mag., 135, 311-330, 1998.

Konstantinovskaya, E. A.: Mesozoic oceanic siliceous, carbonate, and terrigenic rocks at the southeastern Taigonos Peninsula (Northeastern Russia), Lithology and Mineral Deposits, 33(4), 354-368, 1998 (in Russian).

Lagabrielle, Y., Karpoff, A. M., and Cotten, J.: Mineralogical and geochemical analyses of sedimentary serpentinite from conical seamount (hole 778A): implication for the evolution of serpentinite seamount, Proceedings of the Ocean Drilling Program, Scientific results, 125, 325-342, 1992.

Lebedev, Ye. L.: Stratigraphy and age of the OkhotskoChukotskogo volcanic belt, Nauka, Moscow, 175 pp., 1987 (in Russian).

Luchitskaya, M. V.: Geochemical features of East Taigonos and Prybrezhno-Taigonos granitoids in the southern part of Taigonos Peninsula: similarity and difference from I- and M-types of granites, Bulletin, Moskovskogo Obshchestva Ispytateley Prirody, Ser. Geol, 76(3), 52-63, 2001 (in Russian).

Luchitskaya, M. V., Hourigan, J., Bondarentko, G. E., and Morozov, O. L.: New U-Pb SHRIMP data from zircons from granitoids of Pribrezhno- and East-Taigonos belts, southern part of Taigonos Peninsula, Reports RAS, 2003(6), 763-769, 2003 (in Russian).

Markov, M. S.: Metamorphic complexes and "basaltic" layer of the Earth crust of the island arcs, Nauka, Moscow, 232 pp., 1975 (in Russian).

Markov, M. S. and Nekrasov, G. Ye.: Ophiolite of rift zones of the ancient continental crust (Pekulney Range, Chukotka), in: Tectonic Development of the Earth's crust and faults, edited by: Pushcharovsky, Yu. M. and Yanshin, A. L., Nauka, Moscow, 8192, 1979 (in Russian).

Migovich, I. M.: Tectonic Development of the Penzhina-Anadyr Fold Zone, Ph.D. thesis, VSEGEI Press, Leningrad, 24 pp., 1972 (in Russian).

Morozov, O. L.: Geochemistry and lithology of rocks in accretionary prism of the Pekulney Range (Central Chukotka), Lithology and Mineral Deposits, 2, 192-213 (in Russian).

Morozov, O. L.: Geological structure and tectonic evolution of Central Chukotka, oscow, GEOS, Transactions of GIN RAS, 523, 201 pp., 2000 (in Russian).

Nekrasov, G. E.: Tectonics and magmatism of Taiganos and the North-Western Kamchatka, Nauka, Moscow, 158 pp., 2001, 1976 (in Russian).

Nekrasov, G. E. and Lyapunov, S. M.: Melanocratic basement of the Pekulney Range (Chukotka) and evolution trend of the lithosphere of palaeo-oceanic zones of the northeastern frame of the Pacific Ocean, Reports RAS, 297(6), 162-166, 1987 (in Russian).

Nokleberg, W. J., Parfenov, L. M., Monger, J. W. H., Baranov, B. V., Byalobzhesky, S. G., Bundtzen, T. K., Feeney, N. D., Fujita, K., Gordey, S. P., Grantz, A., Khanchuk, A. I., Natal'in, B. A., Natapov, L. M., Norton, I. O., Patton, W. W., Plafker Jr., G., Scholl, D. W., Sokolov, S. D., Sosunov, G. M., Stone, D. B., Tabor, R. W., Tzukanov, N. V., Vallier, T. L., and Wakita, K.: CircumNorth Pacific Tectonostratigraphic terrane map, US Geol. Surv., Open File Rep., 94-714, scale 1:5000 000, 1994. 
Parfenov, L. M.: Continental Margins and Island Arcs in the Mesozoides of Northeastern Asia, Nauka, Novosibirsk, 192 pp., 1984 (in Russian).

Parfenov, L. M., Natapov, L. M., Sokolov, S. D., and Tsukanov, N. V.: Terranes analysis and accretion in northeast Asia, The Island Arc, 2, 35-54, 1993.

Pearce, J. A., Harris, N. B. W., and Tindle, A. G.: Trace element discrimination diagrams for the tectonic interpretation of granitic rocks, J. Petrol., 25, 956-983, 1984.

Pitcher, W. S.: Granites and yet more granites forty years on, Geol. Rundsch., 76, 51-79, 1987.

Pitcher, W. S.: The nature and origin of granite, Chapman and Hall, London, 321 pp., 1993.

Pushcharovsky, Yu. M. and Tilman, S. M. (Eds.): Outline of tectonics of the Koryak Upland, Moscow, Nauka, 220 pp., 1982 (in Russian).

Pushcharovsky, Yu. M., Sokolov, S. D., Tilman, S. M., and Krylov, K. A.: The Northwest Circum-Pacific: Tectonics and Geodynamics, Problems of Tectonics, Mining, and Energy Resources of the Northwestern Pacific, 1, Khabarovsk, DVO ITG AN USSR, 128137, 1992 (in Russian).

Shchepetov, S. V.: Stratigraphy of Cretaceous continental deposits, Northeast Russia, NEISRI, Magadan, 122 pp., 1995 (in Russian).

Silantyev, S., Sokolov, S., Bondarenko, G., Morozov, O., Bazylev, B., Palandzhyan, S., and Ganelin, A.: Geodynamic setting of the high-grade amphibolites and associated igneous rocks from the accretionary complex of Povorotny Cape, Taigonos Peninsular, northeastern Russia, Tectonophysics, 325, 107-132, 2000.

Sokolov, S. D.: Accretionary tectonics of the Koryak-Chukotka segment of the Pacific belt, Trans. of Geological Institute Russian Academy of Sciences, v. 479, Nauka, Moscow, 182 pp., 1992 (in Russian).

Sokolov, S. D. and Byalobzheskiy, S. G.: Terranes of the Koryak Highland, Northeastern Russia, Geotectonics, 30(6), 486-496, 1996 (in Russian).

Sokolov, S. D., Grigoriev, V. N., Peyve, A. A., Batanova, V. G., Krylov, K. A., Luchitskaya, M. V., and Aleksutin, M. V.: The structural and compositional regulation in serpentinite mélanges, Geotectonics, 1, 3-16, 1996 (in Russian).
Sokolov, S. D., Didenko, A. N., Grigoriev, V. N., Alexyutin, M. V., Bondarenko, G. Ye., and Krylov, K. A.: Paleotectonic Reconstructions of Northeastern Russia: Problems and Uncertainties, Geotectonics, 6, 72-90, 1997 (in Russian).

Sokolov, S. D., Lagabrielle, Y., Gerard, J.-K., and Bazylev, B. A.: Geodynamic setting of ultramafic bodies of the Mountaine Dlinnaya (Penzhina region, North-East Russia), Bulletin, Moskovskogo Obshchestva Ispytateley Prirody, Ser. Geol., 75(6), 51-55, 2000 (in Russian).

Thieblemont, D. and Tegyey, M.: Une discrimination geochimique des roches differenciees temoin de la diversite d'origine et de situation tectonique des magmas calco-alcalins, C.R. Acad. Sci. Paris, 319, Serie II, 87-94, 1994.

Tuchkova, I. M., Krylov, K. A., Grigoriev, V. N., and Markevich, P. V.: Problems of sedimentation in the Early Cretaceous forearc basin (Penzhina Bay, Northern Kamchatka), in: Geology and tectonics of platform and orogenic area of Northeast Asia, edited by: Oxman, V. S., YSC SB RAS, Yakutsk, 1, 127-130, 1999 (in Russian).

Vishnevskaya, V. S., Sokolov, S. D., Bondarenko, G. Ye., and Pralnikova, I. E.: New data on age and correlation of volcanic-chert complexes of northwest coast of the Sea of Okhotsk, Reports RAS, 359(1), 66-69, 1998 (in Russian).

Zabrovskaya, N. B.: The inner zone of the Okhotsk-Chukotka Belt on Taigonos, Nauka, Moscow, 199 pp., 1978 (in Russian).

Zhulanova, I. L.: The Earth's Crust of NE Asia in the Precambrian and Paleozoic, Nauka, Moscow, 302 pp., 1990 (in Russian).

Zonenshain, L. P., Kononov, M. V., and Savostin, L. A.: Pacific and Kula/Eurasian relative motions during the last $130 \mathrm{Ma}$ and their bearing on orogensis in northeast Asia, in: Circum-Pacific Orogenic Belts and Evolution of the Pacific Ocean Basin, edited by: Monger, J. W. H. and Francheteau, J., American Geophysical Union, Geodynamics Series, 18, 29-47, 1987.

Zonenshain, L. P., Kuzmin, M. I., and Natapov, L. M.: Geology of the USSR: A plate tectonic synthesis, American Geophysical Union, Geodynamics Series, 21, 242 pp., 1991. 